\title{
Analisis Pajak Penghasilan Terutang Badan Akibat Penerapan Peraturan \\ Pemerintah No. 46 Tahun 2013 serta Kaitannya terhadap Laporan Laba Rugi Perusahaan Studi Kasus PT. Sumber Karunia Laut
}

\author{
*Irma Wijayanti \\ PT. Sumber Karunia Laut, Indonesia
}

DOI: $10.46821 /$ equity.v1i2.174

\begin{abstract}
ABSTRAK
Penelitian ini bertujuan untuk mengetahui sejauh mana PT. Sumber Karunia Laut telah menerapkan Peraturan Pemerintah Nomor 46 Tahun 2013 tentang Pajak Penghasilan Atas Penghasilan dari usaha yang diterima atau diperoleh Wajib Pajak yang memiliki peredaran Bruto tertentu terhadap laporan laba rugi perusahaan. Yang dimana sebelumnya perusahaan ini menggunakan peraturan UU No. 36 Tahun 2008. Untuk menganalisis permasalahan tersebut, maka peneliti menggunakan metode penulisan ini menggunakan metode kualitatif deskriptif. Penelitian yang menggunakan jenis data primer dan sekunder, yang langsung bertanya pada karyawan yang bersangkutan. Hasil penelitian ini menunjukkan bahwa setelah penerapan Peraturan Pemeritah Nomor 46 Tahun 2013 pada laporan Laba Rugi. Perusahaan berdampak pada kecilnya beban pajak yang harus dibayar oleh PT. Sumber Karunia Laut masa pajak tahun 2016 sebesar Rp. 26.393.250 sedangkan sebelum penerapan PP No. 46 Tahun 2013 sebesar Rp. 32.973 .088 sehingga perusahaan menanggung beban pajak lebih kecil sebesar Rp. 6.579.838.
\end{abstract}

Kata Kunci: Peraturan Pemerintah No. 46 Tahun 2013, Laba Perusahaan, UU No. 36 Tahun 2008, Pajak Terutang

\begin{abstract}
This study aims to determine the extent to which PT. Sumber Karunia Laut have applied Government Regulation Number 46 of 2013 on Income Tax on Income from business received or obtained by a Taxpayer having certain Gross Income to the income statement of the company. Which previously the company used the Law no. 36 of 2008. To analyze the problem, the researcher uses this writing method using descriptive qualitative method. The study used primary and secondary data types, which directly asked the employees concerned. The results of this study indicate that after the implementation of Government Regulation Number 46 Year 2013 on the Profit and Loss report. The Company has an impact on the small tax burden that must be paid by PT. Sumber Karunia Laut of tax period 2016 of $R p$. 26,393,250 whereas before the application of PP. 46 Year 2013 of Rp. 32,973,088 so that the company bears a smaller tax burden of Rp. $6,579,838$.
\end{abstract}

Keywords: Government Regulation no. 46 Year 2013, Corporate Profit, Law No. 36 Year 2008, the Tax Due. 


\section{PENDAHULUAN}

Vol. 1 No. 22021

Salah satu sumber pendapatan negara yang terbesar adalah dari sektor pajak. Bagi negara, pajak merupakan salah satu sumber penerimaan penting yang akan digunakan untuk membiayai pengeluaran negara baik pengeluaran rutin maupun pengeluaran pembangunan. Aturan $\mathrm{PPh}$ bagi wajib pajak dengan omset tertentu sudah diberlakukan.Dalam Peraturan Menteri Keuangan (PMK) Nomor: 197/PMK.03/2013 yang ditetapkan tanggal 20 Desember 2013 dan mulai berlaku efektif sejak 1 Januari 2014. Sebagaimana kita ketahui bahwa setiap wajib pajak Orang Pribadi yang melakukan usaha dan Wajib Pajak Badan dengan omset tidak melebihi Rp. 4.800.000.000 dikenakan $\mathrm{PPh}$ final dengan tarif $1 \%$ dari penjualannya.

Perubahan PP 46 bertujuan mengandung beberapa tujuan utama yaitu kemudahan tertib administrasi, tranparansi, peningkatan kontribusi masyarakat dalam pembangunan serta keadilan dalam pengenaan pajak.

PT. Sumber Karunia Laut merupakan perusahaan yang bergerak pada sector manufaktur dalam bidang penjualan seafood(Udang). Penjualan dalam satu tahun dapat mencapai Rp. 2,5 Milyar.

Dengan diterapkannya Peraturan Pemerintah yang baru akankah berpengaruh baik atau tidak terhadap laba rugi perusahaan dibandingkan dengan Perhitungan pajak terutang yang mengacu pada UU No. 36 Tahun 2008. Dilihat bagaimana perusahaan tersebut yang keadaan omsetnya minim.

Berdasarkan uraian diatas, penulis tertarik untuk melakukan penelitian mengenai pajak penghasilan terutang berdasarklan Perubahan PP No. 46 Tahun 2013 sebagai dasar pertimbangan pajak yang dibayar oleh perusahaan maka dalam skripsi ini penulis mengambil judul: "Analisa Pajak Penghasilan Terhutang Badan Akibat Penerapan PP 46 Tahun 2013 Serta Kaitannya Terhadap Laba Rugi Perusahaan (Studi Kasus PT. Sumber Karunia Laut).

\section{TINJAUAN PUSTAKA}

\section{Pengertian Pajak}

"Pengertian pajak menurut Pasal 1 angka 1 UU No. 28 Tahun 2007 tentang Ketentuan Umum dan Tata Cara Perpajakan," Pajak adalah kontribusi wajib kepada Negara yang terutang oleh orang pribadi atau badan yang bersifat memaksa berdasarkan Undang-undang, dengan tidak mendapatkan imbalan secara langsung dan digunakan untuk keperluan negara bagi sebesar-besarnya kemakmuran rakyat".

\section{Fungsi Pajak}

"Menurut Ikatan Akuntansi Indonesia (2018:2), pajak memiliki fungsi yang sangat strategis bagi berlangsungnya pembangunan suatu negara, yaitu sebagai berikut :

a. Fungsi Pajak sebagai Penerimaan (Budgetair)

b. Fungsi Mengatur (Regulatoir)

c. Fungsi Redistribusi

d. Fungsi Demokrasi

\section{Sistem Pemungutan Pajak}

Menurut Ikatan Akuntansi Indonesia (2018:9), sistem pemungutan pajak dapat dibagi menjadi: 
a. Official Assesment System

b. Self Assesment System

c. Withholding System

\section{UU No. 36 Tahun 2008}

Besarnya tarif pajak penghasilan berdasarkan pasal 17 ayat (1) Undang-Undang pajak penghasilan no 36 tahun 2008 untuk Wajib Pajaktarif tunggal sebesar 25\%.

\section{Peraturan Pemerintah Nomor 46 Tahun 2013}

Besarnya tarif pajak penghasilan yang bersifat final sebagaimana dimaksud dalam pasal 2 adalah 1\% (satu persen), pengenaan pajak penghasilan didasarkan pada peredaran bruto dari usaha dalam 1 (satu) tahun dari tahun pajak terakhir sebelum tahun pajak yang bersangkutan dan tidak melebihi Rp 4.800.000.000,00

\section{Penyajian Laporan Keuangan}

Berdasarkan PSAK No.1 (2015:2), laporan keuangan adalah sebagai berikut: "Laporan keuangan merupakan bagian dari proses pelaporan keuangan. Laporan keuangan yang lengkap biasanya meliputi neraca, laporan labarugi, laporan perubahan posisi keangan (yang dapat disajikan dalam berbagai cara misalnya, sebagai laporan arus kas, atau laporan arus dana), catatan dan laporan lain serta materi penjelasan yang merupakan bagian integral dari laporan keuangan. Disamping itu juga termasuk skedul dan informasi tambahan yang berkaitan dengan laporan tersebut, misalnya informasi keuangan segmen industry dan geografis serta pengungkapan pengaruh perubahan harga". Adapun penyajian yang lengkap meliputi: neraca, laporan laba rugi, laporan perubahan ekuitas, laporan arus kas, catatan atas laporan keuangan

\section{METODE PENELITIAN}

Pada penelitian kali ini metode yang digunakan oleh peneliti adalah berupa studi kasus dalam hal ini penelitian akan lebih berpusat pada obyek yaitu perusahaan dan dapat memberikan gambaran yang mendalam tentang obyek penelitian tersebut.

Teknik analisis data yang digunakan dalam penelitian ini yaitu berdasarkan pengamatan terhadap data-data yang diperoleh dari PT. Sumber Karunia Laut. Dari data yang diperoleh tersebut dapat dilakukan analisis sebagai berikut:

a. Mengidentifikasi rumusan masalah dengan cara pengumpulan data, dimulai dari berbagai sumber yaitu melalui wawancara, pengamatan (observasi), dokumentasi dan studi kepustakaan.

b. Menganalisa data yang diperoleh, menghitung besarnya Penghasilan Kena Pajak dan besarnya Pajak Penghasilan yang harus dibayar perusahaan.

c. Menyimpulkan akan hasil dari pembahasan yang telah dilakukan dan memberikan saran kepada PT. Sumber Karunia Laut atas penerapan Peraturan Pemerintah No. 46 Tahun 2013 sebagai dasar kepatuhan dalam hal kewajiban perpajakan.

\section{HASIL DAN PEMBAHASAN}

\section{Analisis Kebijakan Perpajakan Perusahaan}

Dari hasil penelitian dan pengamatan yang dilakukan oleh peneliti, maka terdapat kebijakan perpajakan yang diterapkan oleh PT. Sumber Karunia Laut adalah 
sebagai berikut: Pemilihan metode pembukuan accrual basic, Perencanaan PPN, Aset Tetap, Pendapatan dan Biaya.

Dari data tabel 1, bahwa omset penjualan bersih dari PT. Sumber Karunia Laut mulai dari bulan Januari-Desember 2016 sebesar Rp 2.639.325.000,telah menunjukkan bahwa peredaran bruto di bawah Rp 4.800.000.000, sehingga menerapkan perhitungan Peraturan Pemerintah No. 46 Tahun 2013.

Berikut ini dapat dijelaskan Perhitungan Kewajiban Perusahaan laporan keuangan apabila menggunakan tarif berdasarkan PP No. 46 Tahun 2013 dapat dilihat pada Lampiran 1 dan penjelasan perhitungan laporan keuangan apabila menggunakan tarif sebelum PP No. 46 Tahun 2013 (UU. No. 36 Tahun 2008) dapat dilihat pada Lampiran 2.

\section{Sebelum dan Sesudah Penerapan Peraturan Pemerintah Nomor 46 Tahun} 2013 pada PT. Sumber Karunia Laut

Berdasarkan dari hasil analisa penelitian, dapat disimpulkan bahwa ada tiga pokok yang menjadi titik berat pada PT. Sumber Karunia Laut dalam penerapan Peraturan Pemerintah Nomor 46 Tahun 2013.

Tabel 1

Hasil Rekap Penjualan Tahun 2016 PT. Sumber Karunia Laut

\begin{tabular}{llc}
\hline NO. & BULAN & JUMLAH \\
\hline 1 & JANUARI & $160,237,000$ \\
2 & FEBRUARI & $248,690,000$ \\
3 & MARET & $275,890,000$ \\
4 & APRIL & \\
& Penjualan & $167,970,000$ \\
& Retur Penj. & $3,500,000$ \\
& Pot. Penjualan & $2,000,000$ \\
5 & MEI & $210,589,000$ \\
6 & JUNI & $268,332,000$ \\
7 & JULI & $189,768,000$ \\
8 & AGUSTUS & $189,562,000$ \\
9 & SEPTEMBER & $205,129,000$ \\
10 & OKTOBER & \\
& Penjualan & $185,578,000$ \\
& Retur Penj. & $3,000,000$ \\
& Pot. Penj. & $2,600,000$ \\
11 & NOVEMBER & $258,920,000$ \\
12 & DESEMBER & $289,760,000$ \\
& TOTAL Penjualan Kotor & $\mathbf{2 , 6 5 0 , 4 2 5 , 0 0 0}$ \\
& TOTAL Retur \& Pot & $11,100,000$ \\
& TOTAL Penjualan Bersih & $\mathbf{2 , 6 3 9 , 3 2 5 , 0 0 0}$ \\
\hline
\end{tabular}

Sumber: Data Intern PT. Sumber Karunia Laut 
Tabel 2

PT. Sumber Karunia Laut Perbandingan Laporan Laba Rugi Tahun 2016

\begin{tabular}{lccc}
\hline Keterangan & $\begin{array}{c}\text { Sebelum Penerapan PP 46 Th } \\
\text { 2013 (UU No. 36 Th 2008) }\end{array}$ & $\begin{array}{c}\text { Sesudah Penerapan PP } \\
\text { 46 Th 2013 }\end{array}$ & \multirow{2}{*}{ Selisih } \\
\hline LABA NETTO & 263.784 .700 & 263.784 .700 & - \\
SEBELUM PAJAK & 32.973 .088 & 26.393 .250 & 6.579 .838 \\
PPh Terutang & 230.811 .613 & 237.391 .450 & 6.579 .838 \\
LABA NETTO & SETELAH PAJAK &
\end{tabular}

Sumber : Data Intern Diolah Peneliti

1. Penerapan Tarif

Tarif yang diterapkan pada Peraturan Pemeritah Nomor 46 Tahun 2013 adalah $1 \%$ dari peredaran bruto yang pada peraturan sebelumnya dikenakan tariff berdasarkan Undang-Undang Nomor 36 Tahun 2008 pasal 31 E sebesar 50\% x $25 \%$ dari laba bersih sebelum pajak.

Perbandingan perhitungan kewajiban perpajakan berdasarkan kedua perundangan-undangan perpajakan tersebut dapat dilihat berdasarkan tabel di bawah ini.

Pada tabel 2, dapat dijelaskan bahwa jumlah kewajiban perpajakan apabila menggunakan tarif berdasarkan Peraturan Pemerintah Nomor 46 Tahun 2013 lebih kecil dibandingkan dengan sebelum menggunakan tarif berdasarkan Peraturan Pemerintah Nomor 46 Tahun 2013, sehingga berdampak pada jumlah kewajiban perpajakan perusahaan menjadi lebih kecil sebesar Rp 26.393.250,-. sedangkan jika menggunakan tarif sebelum penerapan Peratutan Pemeritah Nomor 46 Tahun 2013 (Undang-undang No. 36 Tahun 2008) sebesar Rp 32.973.088,-. sehingga perusahaan yang menanggung beban pajak lebih kecil senilai Rp 6.579.838. Kebijakan Pemerintah dalam perubahan peraturan hal ini dapat menguntungkan perusahaan.

2. Pengakuan Biaya

Pada penerapan Peratuan Pemeritah Nomor 46 Tahun 2013 telah diterapkan tarif $1 \%$ dari peredaran bruto yang bersifat final. Oleh karena itu, semua biaya yang dikeluarkan utnuk mendapatakan penghasilan yang bersifat final tidak dapat diakui atau dibebankan.

3. Kompensasi Kerugian

Pada penerapan Peraturan Pemerintah Nomor 46 Tahun 2013, apabila terjadi kerugian atas penghasilan tidak dapat dikompensasikan pada tahun pajak berikutnya.

\section{SIMPULAN}

Perubahan Perpajakan PP Nomor 46 Tahun 2013 tentang Pajak Penghasilan atas Penghasilan dari Usaha yang diterima atau diperoleh Wajib Pajak yang memiliki peredaran Bruto tertentu pada perusahaan PT. Sumber Karunia Laut telah diterapkan pada laporan laba rugi perusahaan, yang dimana sebelumnya perusahaan ini menggunakan perhitungan peraturan Undang-Undang No. 36 tahun 2008. Hal ini dilakukan untuk memenuhi kewajiban perpajakan yang telah ditetapkan oleh Dirjen Pajak. Oleh karena PT. Sumber Karunia Laut hanya memiliki peredaran Bruto tidak lebih dari Rp. 4.800.000.000 maka perusahaan ini 
masuk dalam pengenaan pajak PP No. 46 Tahun 2013. Setelah melakukan penelitian pada PT. Sumber Karunia Laut adapun dampak yang ditimbulkan akibat Penerapan Peraturan Pemerintah No. 46 Tahun 2013 tentang Pajak Penghasilan Atas Penghasilan dari Usaha yang diterima atau diperoleh Wajib Pajak yang memilki peredaran Bruto Tertentu pada Laporan Laba Rugi PT. Sumber Karunia Laut berdampak pada kecilnya kewajiban pajak penghasilan tentang masa pajak 2016 senilai Rp 26.393.250,-. sedangkan jika menggunakan Undang-Undang Nomor 36 Tahun 2008 pajak penghasilan terutang Rp 32.973.088,--sehingga terdapat selisih pada tanggungan beban pajak yang di tanggung oleh PT. Sumber Karunia Laut lebih kecil yakni sebesar Rp 6.579.838. Adanya perubahan peraturan perpajakan yang baru yaitu PP No. 46 Tahun 2013 dengan penerapan tarif tunggal $1 \%$ dari omset yang diperoleh menguntungkan Wajib Pajak yang memiliki profit margin tinggi karena beban pajaknya akan menurun sedangkan bagi yang profit marginnya rendah pajaknya justru meningkat.

\section{DAFTAR PUSTAKA}

Harahap, Sofyan Syafri. 2008. Analisis Kritis Atas Laporan Keuangan. Raja Grafindo Persada. Jakarta.

IAI.2018. Modul Pelatihan Pajak Terapan Brevet A \& B Terpadu. Jakarta.

Larisa, Krismawati. 2014. Penerapan Undang-Undang Perpajakan No. 36 Tahun 2008 (PPh Pasal 25 badan) dan Pengaruhnya pada laporan keuangan Komersial (study kasus PT. Masa Manunggal) Skripsi.Yogyakarta : Universitas Yogyakarta.

Lexy J, Moelong. 2009. Metode Penelitian Kualitatif. Edisi Revisi. Bandung.

Mardiasmo.Perpajakan Edisi Revisi 2011. Yogyakarta: Penerbit Andi. 2011.

Mutia, Citra. 2015. Analisis Pajak Penghasilan Terutang Badan Akibat Peraturan Pemerintah No. 46 Tahun 2013 serta Kaitannya dengan Laba Rugi Perusahaan (study kasus CV. Raja Wali Bima Maju dan PT.New World Rubber Factory) Skripsi.Semarang : Universitas Diponegoro Peraturan Menteri Keuangan (PMK) Nomor. 197/PMK.03/2013.

Peraturan Pemeritah No. 46 Tahun 2013 tentang Pajak Penghasilan Atas Penghasilan dari Usaha yang Diterima Atau Diperoleh Wajib Pajak Yang Memiliki Peredaran Bruto Tertentu terhadap Laba Rugi Perusahaan PSAK No. 1 (Revisi 2009). PT Remaja Rosdakarya.

Rudianto. 2016. Pengantar Akuntansi. Jakarta: Erlangga.

Soedjono, 2015.Hukum Perseroan Terbatas. Jakarta: Penerbit Sinar Grafika. 
Swardjono, 2008.Teori Akuntansi Perekayasaan Pelaporan Keuangan. Edisi Ketiga. Yogyakarta : BPFE.

Tambolon, Sitepu. 2016. Kebijakan Pengurangan Tarif Pajak Penghasilan pada Wajib Pajak Badan Usaha Mikro, Kecil dan Menengah (UMKM) melalui pasal 31E Undang-Undang No. 36 Tahun 2008 Ditinjau dari Azas Keadilan Skripsi. Jakarta: Universitas Indonesia.

Undang-Undang No. 1 pasal 1 tahun 2007 tentang Perseroan Terbatas.

Undang-Udang No. 28 pasal 1 tahun 2007 tentang Ketentuan Umum dan Tata Cara Perpajakan.

Undang-Undang No. 36 Tahun 2008 Tentang Pajak Penghasilan. 
Irma Wijayanti, Analisis Pajak Penghasilan Terutang

Lampiran 1. Laporan Laba Rugi Menggunakan Tarif Berdasarkan PP No. 46 Tahun 2013

\begin{tabular}{|c|c|c|c|c|}
\hline \multicolumn{5}{|c|}{ PT. SUMBER KARUNIA LAUT } \\
\hline \multicolumn{5}{|c|}{ LAPORAN LABA RUGI } \\
\hline \multicolumn{5}{|c|}{ TAHUN 2016} \\
\hline \multicolumn{5}{|c|}{$(\mathrm{Rp})$} \\
\hline Penjualan & & & $2,639,325,000$ & \\
\hline Harga Pokok Penjualan & & & $1,926,054,000$ & - \\
\hline Laba Bruto & & & $713,271,000$ & \\
\hline \multicolumn{5}{|l|}{$\underline{\text { Beban Oprasional }}$} \\
\hline Beban Listrik & & & & \\
\hline Beban Air & & & & \\
\hline Beban Telkom & & & & \\
\hline Beban Penyusutan Peralatan & & & & \\
\hline Beban Penyusutan Gedung & & & & \\
\hline Beban Perlengkapan Kantor & & & & \\
\hline Beban Pemeliharaan Aktiva & & & & \\
\hline Beban Administrasi dan umum & & & & \\
\hline Beban Gaji & & & & \\
\hline \multicolumn{2}{|c|}{ Jumlah Beban Usaha } & & $461,936,300$ & - \\
\hline Laba Usaha & & & $251,334,700$ & \\
\hline Pendapatan Lain-Lain & $12,450,000$ & + & & \\
\hline Laba Netto sebelum Pajak & & & $263,784,700$ & \\
\hline \multicolumn{5}{|l|}{ Pajak Terutang PP. No. 46 Th 2013} \\
\hline $1 \% \times 2.639 .325 .000$ & & & $26,393,250$ & \\
\hline Laba Netto setelah Pajak & & & $237,391,450$ & \\
\hline
\end{tabular}

Sumber : Data Intern PT. Sumber Karunia Laut 
Irma Wijayanti, Analisis Pajak Penghasilan Terutang

Lampiran 2. Laporan Laba Rugi Menggunakan Tarif Sebelum PP No. 46 Tahun 2013

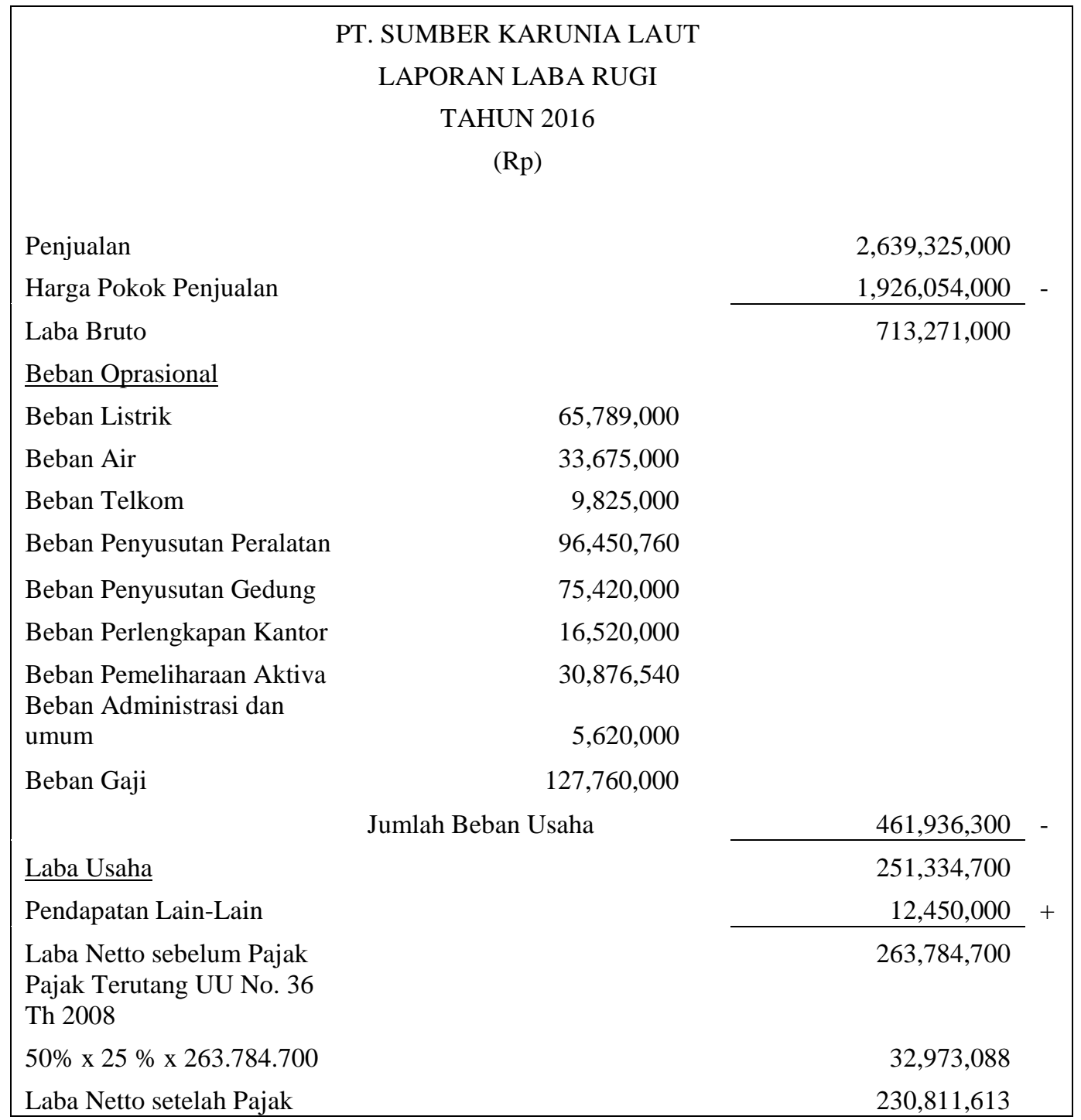

Sumber : Data Intern PT. Sumber Karunia Laut 